DOI 10.15421/4221007

УДК 621.9

О. С. Каіров ${ }^{1}$, д-р техн. наук, О. О. Лимар ${ }^{2}$ канд. фріз. -мат. наук, В. Я. Ошовський ${ }^{1}$ канд. техн. наук

\title{
ВПЛИВ КАР БІДОТИТАНОВИХ ПОКРИТТІВ НА ЗНОСОСТІЙКІСТЬ ТОРЦЕВИХ ФРЕЗ ЗІ ШВИДКОРІЗАЛЬНОЇ СТАЛІ
}

Наведено результати експериментальних досліджень зносостійкості рікучих зубів торцевих фрез зі швидкорізальних сталей 3 карбідотитановим покриттям при обробці конструкційних хромистих сталей. Показано вплив технології нанесення зміцнюючих покриттів на їх структурні параметри і властивості, працездатність ріжучого інструменту. Описана методика проведення експерименту. Виконано рентеноспектральний аналіз хімічного складу поверхневого шару різців. Представлена структура поверхні зносу і крихкого руйнування ріжучих зубів.

Ключові слова: фррезерування; швидкорізальна сталь; карбіди титану; зносостійкість; міцність; твердість; контактні напруження; працездатність.

Вступ. Ріжучі інструменти при обробці твердих і в'язких матеріалів, таких як важкооброблювані конструкційні леговані сталі з підвищеним вмістом хрому, жароміцні сталі і сплави, працюють в умовах впливу циклічних ударних навантажень, високих контактних напружень і температур, що призводить до їх передчасного зносу. Особливо гостро проблема інтенсивного зношування і крихкого руйнування у вигляді відколів і викрошування ріжучих кромок проявляється у торцевих фррез, що працюють на високих швидкостях в умовах переривчастого різання [1, 5-8, 10, 12].

Одним з найбільш ефрективних способів вирішення даної проблеми $\epsilon$ застосування зносостійких покриттів на робочих поверхнях інструменту, що дозволяють значно збільшити втомну міцність, твердість, теплостійкість, залишкові напруження стиснення, корозійну стійкість $[3,6,9,11$, 14]. Найбільш широке застосування отримали карбідотитанові покриття, що мають більш високу зносостійкість і міцність у порівнянні з іншими інструментальними матеріалами. Варіюючи технологію їх нанесення, можна регулювати склад, структуру, а також товщину і твердість [2, 3, 6, $11,14]$. Тому дослідження впливу зміцнюючих покриттів робочих поверхонь торцевої фррези з метою збільшення її зносостійкості і ріжучої здатності в умовах переривчастого різання хромистих конструкційних сталей $€$ актуальним завданням і має практичне значення для підвищення ефективності механічної обробки.

Метою даної роботи є експериментальне дослідження впливу карбідотитанового покриття на зносостійкість ріжучих лез зубів торцевих фррез зі швидкорізальної сталі в умовах переривчастого різання при обробці хромистих конструкційних сталей.

() О. С. Каіров, О. О. Лимар, В.Я. Ошовський, 2021 
Виклад основного матеріалу. Експериментальні дослідження зносостійкості ріжучого інструменту проводилися на вертикально-фррезерному верстаті мод. 6М12П в умовах переривчастого різання при обробці хромистих конструкційних легованих сталей 30ХГСА, 18Х2Н4МА, 20X13 торцевими фррезами $\varnothing 150$ мм, оснащеними п'ятигранними непереточуваними пластинками з швидкорізальних сталей Р 18, Р6М5К5, Р9К5. Обробка різанням проводилася фрезами без покриттів і з покритяям карбіду титану $\mathrm{TiC}$ за схемою зустрічного фррезерування в діапазоні режимів різання: швидкості $V=29,7 \ldots 75,4 \mathrm{M} /$ хв, подачі на зуб $s_{z}=0,05 \ldots 0,2 \mathrm{mм} / 3 у б$, глибині різання $t=1 \ldots 2$ мм, ширині фррезерування $B=50$ мм, без охолодження. Як критерій затуплення інструменту прийнятий максимальний лінійний знос по головній задній поверхні зубів фррез $h_{3}=0,5 \mathrm{~mm}$.

Покриття карбіду титану ТіС наносилися на основу пластин з швидкорізальних сталей на вакуумно-плазмовій установці «Булат-ЗТ». Робочі поверхні ріжучих пластин до і після зносу, а також мікроструктура нанесених покриттів вивчалися методом рентгеноспектрального аналізу за допомогою растрового електронного мікроскопа-мікроаналізатора PEMМА-102-02, електронного мікроскопа РЕМ-100у і металографічного мікроскопа МIM-7. Ренттеноструктурний аналіз покриттів виконувався на дифррактометрі ДРОН-1. Товщина покриття вимірювалася приладом МТ$20 \mathrm{H}$, а його твердість контролювалася приладами ТК-2М і ПМТ-3. Сучасні методи дослідження поверхні наведені в $[4,13,14]$.

Процес формування покриттів з певними фрізико-механічними властивостями, товщиною, структурою і фазовим складом залежить від різних фракторів: опорної напруги, струму дугового розряду випарника, тиску реакційного газу в робочій камері, температури підкладки, щільності потоку осадження і енергії іонів металевої плазми ТіС, тривалості адсорбування.

Попередня підготовка зразків полягала в механічній поліровці та очищенні на ультразвуковій установці. Розігрів установки для напилення поверхневого шару і створення вакууму здійснювався в імпульсному режимі. Після прогріву в камері перед нанесенням покриття виконувалося іонне очищення ріжучих пластин в тліючому розряді.

Нанесення зносостійкого захисного поверхневого шару на ріжучі пластини проводилося за спеціальною іонно-плазмовою технологією методом фізичного осадження покриттів (ФОП) з плазмової фрази за допомогою дугового розряду у вакуумній камері з подальшою подачею реакційного газу. При адсорбуванні конденсату покритя ТіС у вигляді високоіонізованого потоку низькотемпературної плазми на поверхні підкладки відбувається добудова кристалічної решітки. При цьому мікротріщини і пори заповнюються матеріалом покритт, що сприяє підвищенню адгезійної міцності з'єднання «покриття - основа».

Задані характеристики мікротвердості, структури і фразового складу покриттів ТіС забезпечувалися варіюванням трьох основних параметрів режиму конденсації - сили струму дугового розряду випарника $i_{\mathrm{o}}=90 \ldots 150 \mathrm{~A}$, тиску в реакційній камері установки газу-реагенту 
$P_{\alpha}=(5 \ldots 93) \cdot 10^{-2}$ Па і опорної напруги на підкладці $U_{\mathrm{o}}=140 \ldots 200$ B. Час осадження становив 40 хв. Температура конденсації підтримувалася в межах $\theta=450 \ldots 540^{\circ} \mathrm{C}$.

В результаті рентеноспектрального аналізу мікроструктури поверхні ріжучих пластин встановлені оптимальні режими синтезування карбідотитанового покриття на основу 3 швидкоріжучої сталі: $U_{\mathrm{o}}=200 \mathrm{~B}$; $i_{\mathrm{o}}=90 \ldots 120 \mathrm{~A} ; \quad P_{\alpha}=5,3 \cdot 10^{-2}$ Па; $\quad \theta=460 \ldots 500^{\circ} \mathrm{C}$. Дрібнодисперсна структура покриття фрормується при мінімальній силі струму дуги $i_{\mathrm{o}}=90 \mathrm{~A}$. Збільшення струму дугового розряду збіљшує швидкість конденсації.

Ренттеноспектральний аналіз мікроструктури отриманих покриттів показав, що при даному режимі синтезування основна фраза сконденсованого шару складається з ТіС з розмірами кристалітів від 0,004 до 0,033 мкм, без наявності вільного титану.

Експериментально встановлено, що внаслідок низького коефріцієнта теплового розширення карбіду титану, значно меншого в порівнянні 3 швидкорізальною сталлю, на поверхні ріжучих пластин можуть добре утримуватися тільки тонкі покриття товщиною $3 . .10$ мкм. Товсті покриття схильні до розтріскування, особливо при високій температурі. Тому на ріжучі зуби торцевих фррез синтезувалися покриття ТіС товщиною в межах $5 . .8$ мкм, а його мікротвердість складала 23..26 ГПа.

Результати досліджень. Особливістю процесу фррезерування торцевими фррезами в умовах переривчастого різання, що обумовлює циклічний характер термомеханічного навантаження, $є$ ударний вплив при вході і виході ріжучих зубів з контакту з заготівкою, що призводить їх до крихкого руйнування у вигляді відколів або викрошування.

В результаті в ріжучому клині робочої частини інструменту виникає складний напружений стан з одночасною взаємодією нормальних і дотичних напружень. У поверхневому шарі інструментального матеріалу, що прилягає до ріжучої кромки, під дією нормальних сил виникають напруження стиснення, і відбувається пружна дефрормація. У момент виходу зуба фрези з заготовки відбувається знятя навантаження і, відповідно, під дією пружної дедрормації змінюється знак внутрішніх напружень. Напруження стиснення трансформується в розтягувальне, в результаті дії якого, в разі досягнення $\sigma_{b}$ граничного значення, відбувається крихке руйнування десрормованої поверхні інструменту. При цьому частина механічної енергії трансформується в теплову. Частина роботи зовнішніх сил витрачається на підвищення вільної енергії тріщин, а інша частина йде на пружну дефрормацію невеликого обсягу інструментального матеріалу, прилеглого до ріжучої кромки, що призводить до крихкого руйнування. У поверхневому шарі відбувається пружна деформація і виникають втомні процеси, в результаті чого утворюються відколи і мікротріщини.

Проведені дослідження зносу і стійкості торцевих фррез показали, що покриття ТіС істотно знижує адгезійну взаємодію хромистої сталі з конта- 
ктними поверхнями ріжучих зубів практично у всьому діапазоні режимів різання. Ефективність покриттів значно відрізнялася як за величиною, так і за характером взаємодії контактуючої пари. При чистовій обробці ефрективність впливу покриття на інтенсивність зносу в 1,5 ... 2,5 рази вище в порівнянні з чорновою обробкою. Однак після видалення покритя з контактних ділянок адгезійна взаємодія посилюється. На передній і задній поверхнях ріжучої частини інструменту утворюються налипи, які представляють собою розмазаний тонкий шар оброблюваного матеріалу .

Результати дослідження працездатності торцевих фррез з покриттями ТіС при обробці хромистих конструкційних легованих сталей 30ХГСА, 18X2H4MА, 20X13 і вуглецевої сталі 45 представлені в табл. 1.

\section{Таблиця 1 - Результати дослідження працездатності торцевих фрез з покриттями ТіC}

\begin{tabular}{|c|c|c|c|c|c|c|}
\hline \multirow{2}{*}{ 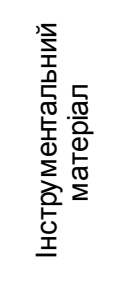 } & \multirow{2}{*}{ 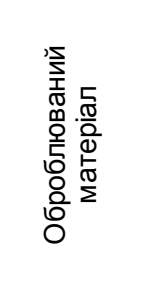 } & \multirow{2}{*}{ 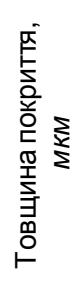 } & \multicolumn{3}{|c|}{ Режими різання } & \multirow{2}{*}{ 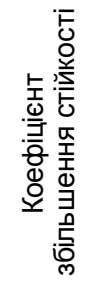 } \\
\hline & & & $\frac{\mathscr{D}}{\Sigma}$ & 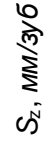 & $\sum_{-\infty}^{\sum}$ & \\
\hline P6M5K5 & Сталь 45 & $6-7$ & 75,4 & \multirow{10}{*}{0,1} & 2 & $2,2-2,7$ \\
\hline P9K5 & Сталь 45 & 5-7 & 75,4 & & 2 & $2,3-2,8$ \\
\hline P18 & Сталь 45 & $5-7$ & 75,4 & & 2 & $2,5-3,2$ \\
\hline P6M5K5 & ЗОХГСА & $6-7$ & $29,6-75,4$ & & 1,5 & $1,8-2,7$ \\
\hline P18 & 30ХГСА & $6-8$ & $29,6-75,4$ & & 1,5 & $1,9-3,1$ \\
\hline P6M5K5 & 18X2H4MA & $6-7$ & $29,6-75,4$ & & 1,5 & $1,7-2,5$ \\
\hline P9К5 & 18X2H4MA & 6-7 & $29,6-75,4$ & & 1,5 & $1,8-2,6$ \\
\hline P6M5K5 & $20 \times 13$ & 5-7 & $29,6-75,4$ & & 1,5 & $1,6-2,6$ \\
\hline Р9к5 & $20 \times 13$ & $5-7$ & $29,6-75,4$ & & 1,5 & $1,7-2,6$ \\
\hline $\begin{array}{l}\mathrm{P} 18 \\
\end{array}$ & $20 \times 13$ & $6-7$ & $29,6-75,4$ & & 1,5 & $1,8-2,8$ \\
\hline
\end{tabular}

Отримані результати показали високу ефрективність впливу карбідотитанового покриття на знос і стійкість фррез. Залежності стійкості $T$ і коефіцієнта відносного підвищення стійкості $K_{\mathrm{o}}$ фрез з швидкорізальної сталі Р9К5 від швидкості різання $V$ представлені на рис. 1 для параметрів режиму різання: $s_{z}=0,1 \mathrm{~m} / 3 у б ; t=1,5 \mathrm{мm}$. Коефіцієнт $K_{\mathrm{o}}=T_{1} / T_{2}$ визначався як відношення стійкості $T_{1}$ фрез з карбідотитановим покриттям до стійкості $T_{2}$ незміцнених фрез.

3 наведених результатів видно, що у всьому діапазоні швидкості різання стійкість фррез з зносостійким покриття перевищує стійкість без

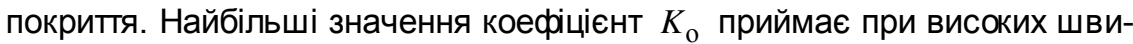
дкостях різання, а найменше - при малих швидкостях. Так, величина 


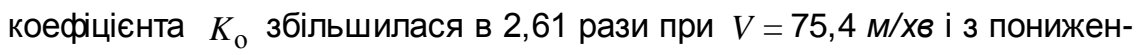
ням швидкості до $V=29,7 \mathrm{~m} /$ хв величина коефіцієнта $K_{\text {о }}$ зменшилася до 1,67. Особливо помітно вплив покриття проявляється в початковий період роботи, коли знос інструменту зростає і коефріцієнт відносного збільшення стійкості $K_{\text {о }}$ досягає значення 3...8. При зменшенні величини зносу, величина $K_{\text {о }}$ знижується до 1,5...3,5.

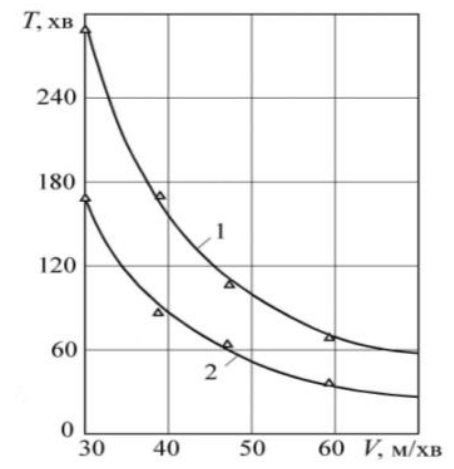

a)

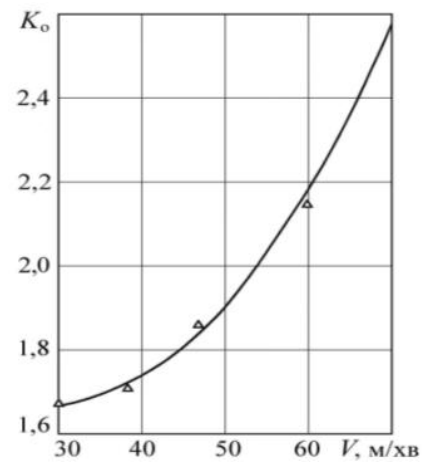

б)

Рис. 1 - Залежності стійкості $T$ і коефіцієнта відносного підвищення стійкості $K_{\text {о }}$ торцевих фрез зі швидкорізальної сталі Р9К5 від швидкості різання $V$ при обробці сталі 20X13: 1 - 3 покриттям ТіC; 2 - без покриття

При різанні пластинами без покриття передня поверхня зубів фррез по всій ширині зрізу внаслідок адгезійного схоплювання покривалася налипами вже в початковий період обробки. Схоплювання виникало у всьому діапазоні швидкості різання $29,7 \leq V \leq 75,4 \mathrm{~m} / \mathbf{\text { в }}$.

Встановлено, що високі фізико-механічні властивості, низька теплопровідність і схильність до зміцнення погіршують оброблюваність хромистих сталей. Тому процес різання супроводжується значним термосиловим навантаженням. Сили різання при обробці хромистих сталей в 3..4 рази перевищують сили, що виникають при обробці вуглецевих сталей. Питомий тиск при різанні доходить до 400..1200 МПа, а низька теплопровідність збільшує температуру різання на $30 . .50 \%$.

При обробці хромистих сталей абразивно-механічний знос протікає в умовах активної адгезійної взаємодії, яка полягає в схоплюванні в процесі тертя інструментального матеріалу зі стружкою оброблюваного матеріалу, що призводить до різкого підвищення зносу і зниження стійкості інструменту. При цьому робочі поверхні інструменту в процесі тертя через пластичні дефрормації нерівностей при схоплюванні піддаються наклепуванню. Стійкість інструменту через крихке руйнування у вигляді відколів і викрошування ріжучих кромок знижується в 1,5..3 рази. Отже, 
сколоутворення $є$ однією з найважливіших причин істотного зменшення ресурсу роботи інструменту.

Аналіз налиплих елементів наклепу на задній робочій поверхні ріжучих зубів при обробці сталі 20X13 показав, що основними складовими поверхневого шару інструменту є залізо (Fe) і хром (Cr), які відповідають хімічному складу оброблюваного матеріалу. Концентрація цих елементів коливається в межах: $\mathrm{Cr} 13 . .15 \%$, вуглецю (C) 0,16..0,25 \% та Fe 85..86 \%. Аналогічні результати отримані і для інших оброблюваних матеріалів.

Зміцнююче покриття, зберігаючи в'язкість і міцність основи - швидкорізальної сталі і, маючи високу твердість і зносостійкість, оберігає інструментальний матеріал весь період його роботи. Істотно знижуються адгезійні процеси, що виникають на контактних ділянках інструменту і заготовки. Зменшується тертя, сили різання і схоплювання, а також теплота, що виділяється при цьому.

Низька теплопровідність карбіду титану змінює характер тепловідведення із зони різання, перешкоджає відведенню тепла в інструмент і сприяє зростанню відведення тепла в стружку. Встановлено, що температура різання торцевих фррез Р6М5К5 з карбідотитановим покриттям на $11 . .18 \%$ менше в порівнянні з фррезами без покриттів.

На рис. 2 показаний знос по головній задній поверхні п'ятигранної пластинки Р6М5К5 з покриття ТіC при обробці сталі 20 X13 для параметрів режиму різання: $V=58,9 \mathrm{M} / \mathrm{x}, t=1,5 \mathrm{~mm}, s_{z}=0,1 \mathrm{~mm} /$ зуб та періоду роботи $\tau=80$ хв.

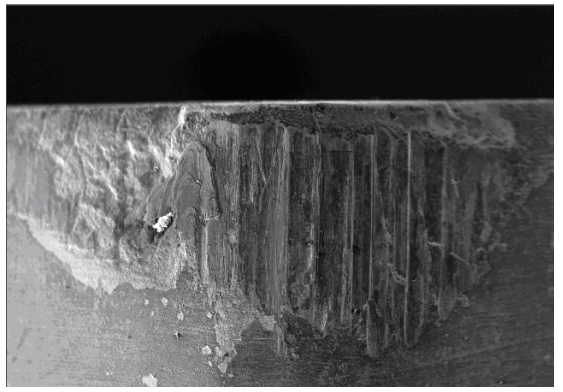

a)

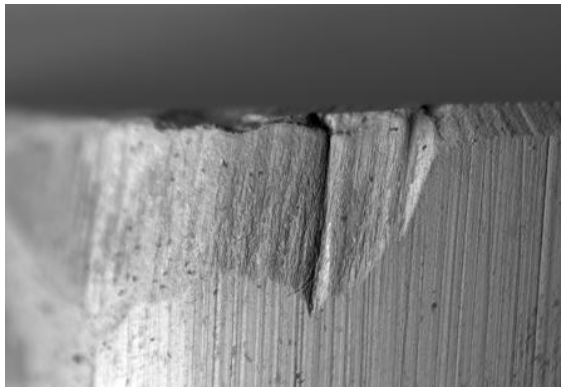

6)

Рис. 2 - Структура зносу по задній поверхні різців з швидкорізальної сталі Р6М5К5 при фрезеруванні сталі 20X13: а) 3 покриттям; б) без покриття

Топографрія зношеної поверхні (рис. 2,a), яка отримана на растровому електронному мікроскопі, має рельєфність у вигляді налипу, обумовленого наявністю великої кількості дефромованих виступів, що представляють собою частинки матеріалу заготовки, розмазаного по ріжучої поверхні пластини. Це свідчить про значні пластичні деформації в зоні різання на контактних ділянках інструменту і заготовки. Виступи та канавки, що їх розділяють, розташовані у напрямку руху пари «інструмент - заготівка». Видно, що знос по довжині ріжучої кромки проходить нерівномірно і досягає найбільшого значення по радіусному переходу від головної задньої поверхні до допоміжної. У цій області створюються 
найбільш важкі умови роботи інструменту (висока температура, великі напруження), що збільшує інтенсивність зносу. Наявність покриття ТіС істотно знижує інтенсивність зносу і схоплювання, як передньої, так і головної задньої поверхні, але не запобігає їх повністю.

Крихке руйнування ріжучої кромки у вигляді локальних відколів з боку головної задньої поверхні спостерігається на рис. 2,б і утворюється протягом усього періоду роботи інструменту, але найбільш інтенсивно в початковий період роботи. Характерним для цих відколів $€$ те, що вони розташовані на перифрерійній ділянці головної ріжучої кромки. У цій зоні виникає перехід від пружно-напруженої області різця до ненавантаженої, і тому там виникають розтягувальні напруження, які призводять до крихкого руйнування різця уздовж ріжучої кромки. Руйнування в умовах переривчастого різання починається з утворення на передній поверхні інструменту поздовжніх тріщин, перпендикулярних до головної ріжучої кромки, які ростуть в сторону задньої поверхні і надалі виходять на неї. Одночасно збільшується лунка зносу на передній поверхні і ділянка зносу на задній поверхні. В процесі роботи в зоні крихкого руйнування ріжучої кромки формується уступ в результаті мікровикрошування гострих кромок, виступів, а також виривів частинок швидкорізальної сталі, що перешкоджають руху стружки.

Також видно характерні ознаки інтенсивної адгезійної взаємодії матеріалу стружки з поверхнею зуба фррези у вигляді зносу по головній задній поверхні. Процес зношування передньої поверхні зубів фррез супроводжувався утворенням відколів і лунок. У зоні різання через високі питомі навантаження і температуру матеріал заготовки переходить в пластичний перебіг, заповнюючи обсяг уступу. Лунки, тріщини, канавки заповнюються металом заготовки. В результаті формується модифікований ріжучий клин і процес зношування набуває форми абразивномеханічного зносу. Подальший знос відбувається у формі механічного стирання по головній задній поверхні.

Зміцнення ріжучих зубів фррез за запропонованою методикою дозволяє підвищити їх зносостійкість, уникнути крихкого руйнування ріжучих кромок і знизити інтенсивність сколоутворення протягом усього періоду роботи інструменту. При цьому задні поверхні піддаються нормальному зносу стиранням. Карбідотитанове покриття, зберігаючи в'язкість і міцність основи і, маючи високу твердість і зносостійкість, оберігає інструментальний матеріал на всьому протязі його роботи, знижує сили різання на $10 \ldots 20 \%$ і коефріцієнт усадки стружки на $8 . . .16 \%$ за рахунок зменшення тертя і пластичної деформації зрізуваного металу. Істотно знижуються адгезійні процеси, що виникають на контактуючих поверхнях інструменту і заготовки. Зменшується тертя, сили різання і схоплювання, а також теплота, що виділяється.

Висновки. Встановлено закономірності зносу і стійкості торцевих фррез зі швидкорізальних сталей з карбідотитановим покриттям в умовах переривчастого різання хромистих конструкційних сталей, що дозволяють підвищити продуктивність обробки.

Виявлено, що наявність зміцнюючого поверхневого шару на ріжучих кромках інструменту призводить до істотної зміни характеру контактних 
процесів, зниження інтенсивності крихкого руйнування і зменшення температури в зоні різання, зниження інтенсивності зносу і збільшення стійкості інструменту в $1,7 \ldots 2,4$ разів.

\section{БІБЛІОГРАФІЧНІ ПОСИЛАННЯ}

1. Армарего И. Дж., Браун Р. Х. Обработка металлов резанием. М.: Машиност роение, 1977. 326 с.

2. Верещака А. С. Работоспособность режущего инст румента с износостойкими покрып иями. М.: Машиностроение, 1993. 336 с.

3. Внуков Ю. Н., Марков А. А., Лаврова Л. В. Нанесение износостойких покрытий на быстрорежущий инструмент. К.: Тэхника, 1992. 143 с.

4. Вудроф Д., Делгар Т. Современные методы исследования поверхности. М.: Мир, 1989. 564 с.

5. Геллер Г. А. Инструментальные стали. М.: Металлургия, 1983. 526 с.

6. Кипарисов С. С., Левинский Ю. В., Петров А. П. Карбид титана: получение, св ойства, применение. М.: Металлургия, 1987.216 с.

7. Лоладзе Т. Н. Прочность и износостойкость режущего инструмента. М.: Машиностроение, 1982. 320 с.

8. Макаров А. Д. Износ и стойкость режущего инструмента. М.: Машиностроение, 1978.264 с.

9. Мацевитый В. М. Покрьтия для режущих инструментов. Харьков: Вища школа, 1987. 128 с.

10. Остафьев В. A. Расчет динамической прочности режущего инструмента. М.: Машиностроение, 1979. 168 с.

11. Табаков В. П. Формирование износостойких ионно-плазменных покрытий режущего инст румента. М.: Машиностроение, 2008. 311 с.

12. Талантов Н. В. Физические основы процесса резания, изнашивания и разрушения режущего инструмента. М.: Машиностроение, 1992. 240 с.

13. Уманский Я. С., Скаков Ю.А., Иванов А. И. Кристаллография, рентгенография и электронная микроскопия. М.: Металлургия, 1982. 632 с.

14. Хокинг М., Васантасри В., Сидки П. Металлические и керамические покрытия: Получение, свойства и применение. М.: Мир, 2000. 518 с.

УДК 621.9

А. С. Каиров ${ }^{1}$, д-р техн. наук, А. А. Лимарь ${ }^{2}$, канд. фриз. -мат. наук, В. Я. Ошовский ${ }^{1}$ канд. техн. наук

\section{ВЛИЯНИЕ КАРБИДОТИТАНОВЫХ ПОКРЫТИЙ НА ИЗНОСОСТОЙКОСТЬ ТОРЦОВЫХ ФРЕЗ ИЗ БЫСТРОРЕЖУЩЕЙ СТАЛИ}

Приведены результаты экспериментальных исследований износостойкости режущих зубьев торцовьх фрез из быстрорежущих сталей с карбидотитановым покрытием при обработке конструкционных хромистых сталей. Показано влияние технологии нанесения упрочняющих покрытий на их структурные параметры и свойства, работоспособность режущего инструмента. Описана методика проведения эксперимента. Выполнен рентгеноспектральный анализ химического состава поверхностного слоя резцов. Представлена структура поверхности износа и хрупкого разрушения режуших зубьев.

Ключевые слова: фррезерование; быстрорежущая сталь; карбиды титана; износостойкость; прочность; твердость; контактные напряжения; работоспособность. 


\section{A. S. Kairov', Dr. Sci. (Tech.), A. A. Lymar², PhD (Phys.-Math), V. Ya. Oshovsky ${ }^{1}, \mathrm{PhD}$ (Tech.) \\ INFLUENCE OF CARBIDOTITANE COATINGS ON WEAR RESISTANCE OF HIGH-SPEED STEEL END MILLS}

The results of experimental studies of the wear resistance of the cutters of end mills made of high-speed steels with carbide-titanium coating during the processing of structural chromium steels are presented. The influence of the technology of applying hardening coatings on their structural parameters and properties, the efficiency of the cutting tool is shown. The method of conducting the experiment is described. X-ray spectral analysis of the chemical composition of the surface layer of incisors was performed. The structure of the wear surface and brittle fracture of the cutting teeth is presented.

Keywords: milling; high-speed steel; titanium carbides; wear resistance; strength; hardness; contact stresses; efficiency.

Cutting tools for processing hard and viscous materials, such as hard-toprocess structural alloy steels with a high chromium content, heat-resistant steels and alloys, work under the influence of cyclic impact loads, high contact stresses and temperatures. This leads to their premature wear. The problem of intensive wear and brittle destruction in the form of chips and chipping of the cutting edges is especially reveal in end mills that operate at high speeds in intermittent cutting conditions [1, 5-8, 10, 12].

One of the most effective ways to solve this problem is the use of wearresistant coatings on the working surfaces of tools, which can significantly increase fatigue strength, hardness, heat resistance, residual compression stresses, corrosion resistance $[3,6,9,11,14]$. The most widely used are carbide titanium coatings, which have higher wear resistance and strength compared to other tool materials. The composition, structure, thickness and hardness of the coating can be adjusted by varying the technology of their application [2, 3, 6, 11, 14]. Therefore, the study of the effect of hardening coatings on the working surfaces of an end mill in order to increase its wear resistance and cutting ability in conditions of intemittent cutting of chromium structural steels is an urgent task and has practical importance for increasing the efficiency of machining.

The aim of the work is an experimental study of the effect of a carbide titanium coating on the wear resistance of cutting blades of cutters of end mills made of high-speed steel under intermittent cutting conditions when processing chromium structural steels.

Abrasive and mechanical wear during the processing of chromium steels is carried out under conditions of active adhesive interaction and consists in sticking together in the process of friction of the tool material with the chips of the processed material. This leads to a sharp increase in wear and a decrease in tool life. Therefore, the working surfaces of the tool in the process of friction due to plastic deformation of unevenness during seizure are subjected to work hardening. Tool durability due to brittle fracture in the form of chips and chipping of cutting edges decreased by 1.5...3 times. 
The hardening of the cutting teeth of the cutters according to the proposed method makes it possible to increase their wear resistance, avoid brittle fracture of the cutting edges and reduce the intensity of chipping throughout the entire period of the tool operation. In this case, the rear surfaces are subject to normal abrasion wear. Titanium carbide coating, maintaining the toughness and strength of the base and, having high hardness and wear resistance, protects the tool material throughout its operation, reduces cutting forces by $10 . .20 \%$ and the shrinkage ratio of chips by $8 . .16 \%$ due to the reduction of friction and plastic deformation of the cut metal.

Adhesion processes occurring on the contacting surfaces of the tool and the workpiece are significantly reduced. Friction is reduced, as well as the heat generated, cutting forces and setting.

\section{REFERENCES}

1. Armarego I. D., Brawn R. H. Metal cutting processing. Moscow: Mashinostroenie, 1977. 326 p. (in Russian).

2. Vereshchaka A. S. Operability of the cutting tool w ith w ear-resistant coatings. Moscow: Mashinostroenie, 1993. 336 p. (in Russian).

3. Vnukov Yu. N., Markov A. A., Lavrova L. V. Application of wear-resistant coatings on high-speed tools. Kiev: Tekhnika, 1992. 143 p. (in Russian).

4. Woodrof D., Delgar T. Modern methods of surface research. Moscow: Mir, 1989. 564 p. (in Russian).

5. Geller G. A. Tool steels. Moscow: Metalurgia, 1983.526 p. (in Russian).

6. Kiparisov S. S., Levinskyi Yu. V., Petrov A. P. Titanium carbide: production, properties, application. Moscow: Metalurgia, 1987. 216 p. (in Russian).

7. Loladze T. N. Strength and wear resistance of the cutting tool. Moscow: Mashinostroenie, 1982. 320 p. (in Russian).

8. Makarov A. D. Wear and resistance of the cutting tool. Moscow: Mashinostroenie, 1978. 264 p. (in Russian).

9. Matsevityi V. M. Coatings for cutting tools. Kharkiv: Vysshaya shkola, 1987. 128 p. (in Russian).

10. Ostafyev V. A. Calculation of the dynamic strength of the cutting tool. Moscow: Mashinostroenie, 1979. 168 p. (in Russian).

11. Tabakov $\boldsymbol{V}$. $\boldsymbol{P}$. Formation of wear-resistant ion-plasma coatings of cutting tools. Moscow: Mashinostroenie, 2008. 311 p. (in Russian).

12. Talantov $\boldsymbol{N}$. $\boldsymbol{V}$. The physical basis of the cutting process, wear and destruction of the cutting tool. Moscow: Mashinostroenie, 1992. 240 p. (in Russian).

13. Umanskyi Ya. S., Skakov Yu. A., Ivanov A. I. Crystallography, radiography and electron microscopy. Moscow: Metalurgia, 1982. 632 p. (in Russian).

14. Hawking M., Vasantasri V., Sidki P. Metal and ceramic coatings: Production, properties and application. Moscow: Mir, 2000.518 p. (in Russian).

\footnotetext{
${ }^{1}$ Національний університет

Миколаїв, Україна

${ }^{2}$ Миколаївський національний

аграрний університет,

Миколаїв, Україна
}

кораблебудування імені адмірала Макарова

Надійшла до редколеаії 07.10.2021 